\title{
Delta-Like Protein 1
}

National Cancer Institute

\section{Source}

National Cancer Institute. Delta-Like Protein 1. NCI Thesaurus. Code C106586.

Delta-like protein 1 (723 aa, $78 \mathrm{kDa}$ ) is encoded by the human DLL1 gene. This protein is involved in cell fate decisions during hematopoiesis. 